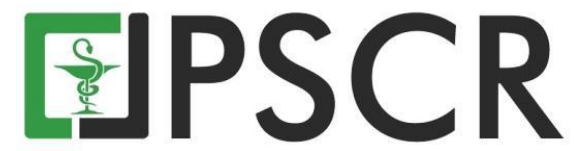

\title{
Kajian Potensi Inkompatibilitas dan Instabilitas: Studi Kasus Sediaan Racikan Mengandung Amitriptilin, Trifluoperazine Dihidroklorida dan Alprazolam
}

\section{Desi Amroni Kasanah ${ }^{1}$, Dina Christin Ayuning Putri ${ }^{2 *}$, Sri Hartati Yuliani ${ }^{3}$ dan Rini Dwiastuti $^{3}$}

\author{
Program Studi Profesi Apoteker, Fakultas Farmasi, Universitas Sanata Dharma \\ Program Studi Farmasi, Fakultas Farmasi, Universitas Sanata Dharma \\ Program Studi S2 Farmasi, Fakultas Farmasi, Universitas Sanata Dharma \\ *email korespondensi : dinachristin@usd.ac.id
}

\begin{abstract}
Abstrak: Meracik obat merupakan salah satu tugas tenaga kefarmasian. Peracikan obat merupakan salah satu risiko penyebab medication error. Resep racikan yang mengandung amitriptilin, trifluoperazin dihidroklorida dan alprazolam adalah jenis peresepan dengan tingkat risiko tinggi, sedangkan informasi tentang sediaan racikan kombinasi obat tersebut masih sangat terbatas. Studi ini bertujuan untuk memberikan informasi mengenai risiko peracikan, potensi instabilitas, dan potensi inkompatibilitas pada resep racikan sediaan kapsul yang mengandung amitriptilin, trifluoperazin dihidroklorida dan alprazolam di sebuah rumah sakit di Semarang. Analisis risiko resep dilakukan dengan memperhatikan aspek risiko teknis dan risiko klinis, sedangkan pengkajian terhadap potensi instabilitas dan inkompatibilitas dilakukan secara sistematis menggunakan beberapa literatur sengan kriteria yang telah ditetapkan. Hasil analisis risiko menunjukkan bahwa resep racikan mengandung amitriptilin, trifluoperazin dihidroklorida dan alprazolam memiliki risiko peracikan yang sangat tinggi. Berdasarkan penelusuran literatur sistematis, ditemukan adanya potensi ketidakstabilan dan inkompatibilitas yang mungkin terjadi yaitu penarikan lembab dan reaksi hidrolisis. Berbagai upaya teknis dapat dilakukan oleh tenaga kefarmasian untuk meningkatkan kualitas obat dan menjamin keamanannya yaitu menggunakan cangkang kapsul HPMC, menyimpan sediaan dalam wadah tertutup kedap, terhindar dari cahaya langsung pada suhu ruang dan menambahkan silika gel. Meskipun demikian, potensi instabilitas dan inkompatibilitas yang ditemukan dalam studi ini masih berdasar pada kajian pustaka, sehingga perlu dilakukan penelitian eksperimental untuk mengetahui profil stabilitas dan kompatibilitas sediaan racikan tersebut.
\end{abstract}

Kata kunci: Peracikan obat; Inkompatibilitas; Instabilitas; Amitriptilin; Trifluoperazine dihidroklorida, alprazolam.

\begin{abstract}
Assessment of Instability and Incompatibility: A Case Study of Compounding Drug Containing Amitriptyline, Trifluoperazine Dihydrochloride and Alprazolam. The responsibilities of a pharmacist are drug compounding. It might cause medication errors. Combination of amitriptyline, trifluoperazine dihydrochloride and alprazolam was a high-risk compounding prescribing meanwhile its formula information was still few. Therefore, this study aimed to provide information about the risk of compounding, potential instability, and potential incompatibilities in the prescription of capsules containing amitriptyline, trifluoperazine dihydrochloride and alprazolam in a hospital located in Semarang. Compounding risk analysis was carried out concerning aspects of technical risk and clinical risk, while the assessment of potential instability and incompatibility was carried out systematically using some literature with predetermined criteria. The results of the risk analysis
\end{abstract}


showed that prescription concoctions containing amitriptyline, trifluoperazine dihydrochloride and alprazolam had a very high risk of compounding. Based on systematic literature searches, it was founded that there was potential for instability and incompatibilities that might occur in the form of humidity uptake and hydrolysis reactions. Several efforts could be made to minimize the risk of errors and to maintain the stability of the drug. A Pharmacist must be done a risk assessment for a high frequent prescribed drug as a quality assurance practice in pharmaceutical compounding. Having a good ability in understanding the physical and chemical properties of medicine to be able to estimate the stability and incompatibility in the preparation of drug compounding and find the best solution to overcome these problems.

Keywords: Compounding; Incompatibility; Instability; Amitriptyline; Trifluoperazine Dihydrochloride; Alprazolam

\section{Pendahuluan}

Obat racikan masih belum bisa dihilangkan dari pelayanan kefarmasian untuk memfasilitasi dokter yang mencampurkan lebih dari 1 zat aktif menjadi 1 bentuk sediaan dengan tujuan meningkatkan ketaatan pasien dalam mengkonsumsi obat (Wiedyaningsih and Suryawati 2013). Meskipun demikian, dalam peracikan obat terdapat berbagai resiko yang bisa terjadi, sehingga berpotensi menyebabkan medication error atau kesalahan terapi. Kesalahan tersebut dapat terjadi di berbagai tahap dalam pelayanan resep, yaitu fase peresepan, pembacaan resep, penyiapan hingga penyerahan obat, dan penggunaan obat (Amalia and Sukohar 2014).

Peracikan obat rentan menyebabkan kesalahan dalam terapi, terkait dengan kualitas sediaan farmasi, infeksi sekunder, bahkan meningkatkan resiko efek samping obat hingga kematian (Boodoo, 2010; Chollet and Jozwiakowski, 2012). Hal tersebut disebabkan karena informasi mengenai kualitas sediaan dan keamanan masing-masing sediaan racikan belum diketahui atau belum dilakukan studi (Gudeman et al., 2013). Tugas seorang apoteker adalah menjamin bahwa sediaan racikan yang dihasilkan harus aman dan efektif, sehingga perlu dilakukan skrining terhadap resep.

Tenaga kefarmasian perlu melakukan pengkajian resep sebelum meracik obat, salah satunya dengan memperhatikan stabilitas, pKa, ukuran partikel, dan karakteristik penting lainnya yang diperoleh melalui studi literatur (Nahata and Allen, 2008). Namun, keterbatasan waktu dan sumber daya manusia menyebabkan proses pengkajian resep menjadi tidak optimal. Beberapa aspek yang perlu ditinjau lebih lanjut adalah risiko peracikan dan juga aspek farmasetis (stabilitas dan kompatibilitas).

Resep racikan sediaan kapsul mengandung amitriptilin, trifluoperazin dihidroklorida dan alprazolam merupakan contoh peracikan yang dilakukan di salah satu rumah sakit swasta di Semarang. Namun informasi tentang risiko, stabilitas, dan kompatibilitas yang komprehensif mengenai sediaan racikan tersebut masih belum tersedia. Studi ini bertujuan untuk memberikan 
informasi mengenai risiko peracikan, potensi instabilitas, dan potensi inkompatibilitas pada resep racikan sediaan kapsul yang mengandung amitriptilin, trifluoperazin dihidroklorida dan alprazolam. Hasil studi ini diharapkan mampu memberikan gambaran bagi praktisi dalam melakukan peracikan sediaan tersebut, supaya dapat menghasilkan sediaan yang aman dan efektif bagi pasien.

\section{Metode}

Studi ini bersifat observasional deskriptif menggunakan metode kepustakaan. Data resep diperoleh dari sebuah rumah sakit swasta di Semarang. Penelitian ini telah mendapatkan ijin dari komite rumah sakit dengan nomor 621/RSX/LP/DIKLAT/VII/2018. Kombinasi amitriptilin, trifluoperazin dihidroklorida dan alprazolam merupakan salah satu resep racikan sediaan kapsul yang dianggap memiliki risiko tinggi oleh tenaga kefarmasian di rumah sakit tersebut. Penelitian dilakukan dengan melakukan analisis risiko serta analisis potensi instabilitas dan inkompatibilitas pada kombinasi obat tersebut.

Analisis resiko dilakukan menggunakan matriks analisis resiko (Tabel 1 dan Tabel 2) berdasarkan Handbook of Extemporaneous Preparation (Jackson and Lowey, 2010). Secara umum analisis resiko terbagi menjadi 2 aspek yaitu resiko teknis dan resiko klinis. Total skor analisis risiko adalah jumlah skor analisis risiko teknis dan risiko klinis. Hasil skor total risiko diklasifikasikan menjadi rendah (nilai <5), sedang (nilai 5-10), tinggi (0-15), dan sangat tinggi (nilai $>15)$.

Tabel 1. Matriks Risiko Teknis berdasarkan Handbook of Extemporaneous Preparation (Jackson and Lowey 2010).

\begin{tabular}{|c|c|c|c|}
\hline \multirow{2}{*}{ Kerumitan Perhitungan* } & \multicolumn{3}{|c|}{ Kerumitan proses peracikan** } \\
\hline & Rendah & Sedang & Tinggi \\
\hline Sederhana & $\begin{array}{c}\text { Box A } \\
\text { (skor 2) }\end{array}$ & $\begin{array}{l}\text { Box B } \\
\text { (skor 4) }\end{array}$ & $\begin{array}{c}\text { Box C } \\
\text { (skor 6) }\end{array}$ \\
\hline Sedang & $\begin{array}{c}\text { Box D } \\
\text { (skor 4) }\end{array}$ & $\begin{array}{c}\text { Box E } \\
\text { (skor 6) }\end{array}$ & $\begin{array}{c}\text { Box F } \\
\text { (skor 8) }\end{array}$ \\
\hline Sangat Rumit & $\begin{array}{c}\text { Box G } \\
\text { (skor 6) }\end{array}$ & $\begin{array}{l}\text { Box H } \\
\text { (skor 8) }\end{array}$ & $\begin{array}{c}\text { Box I } \\
\text { (skor 10) }\end{array}$ \\
\hline $\begin{array}{lll}\text { *Justifikasi kerumitan perhitungan } \\
- & \text { Sederhana } & \text { : tanpa perhitungan } \\
- & \text { Sedang } \quad \text { : perhitungan denga } \\
- & \text { Rumit } \quad \text { : perhitungan denga } \\
\text { **Justifikasi kerumitan proses peraci } \\
- & \text { Rendah } \quad: \text { melibatkan } \leq 3 \text { tah } \\
- & \text { Sedang } \quad: \text { melibatkan } 4-5 \text { tal } \\
- & \text { Tinggi } \quad: \text { melibatkan }>6 \text { tal }\end{array}$ & $\begin{array}{l}\text { gan dengan } \\
\text { tkan perubah } \\
\text { tkan perubah } \\
\text { ikan } \\
\text { ikan atan pe }\end{array}$ & $\begin{array}{l}\text { engurangan, } \\
\text { In masih dala } \\
\text { unit (satuan } \\
\text { Inakan alat k }\end{array}$ & $\begin{array}{l}\text { n perkalian sederhan } \\
\text { ontoh mg ke g) } \\
\text { ot), pengenceran } \\
\text { homogenator) }\end{array}$ \\
\hline
\end{tabular}


Tabel 2. Matriks Risiko Klinis berdasarkan Handbook of Extemporaneous Preparation (Jackson and Lowey, 2010).

\begin{tabular}{|c|c|c|c|}
\hline \multirow{2}{*}{ Efek samping yang ditimbulkan* } & \multicolumn{3}{|c|}{ Indeks Terapetik $(\mathbf{I T})^{* *}$} \\
\hline & Luas & Medium & Sempit \\
\hline $\begin{array}{l}\text { (A) Efek samping minor, tetapi } \\
\text { morbiditas yang signifikan tidak } \\
\text { terjadi }\end{array}$ & $\begin{array}{l}\text { Box A } \\
\text { (skor 2) }\end{array}$ & $\begin{array}{l}\text { Box B } \\
\text { (skor 4) }\end{array}$ & $\begin{array}{l}\text { Box C } \\
\text { (skor 6) }\end{array}$ \\
\hline $\begin{array}{l}\text { (B) Efek samping sedang yang } \\
\text { muncul akibat dari obat yang } \\
\text { underdose atau overdose }\end{array}$ & $\begin{array}{l}\text { Box D } \\
\text { (skor 4) }\end{array}$ & $\begin{array}{l}\text { Box E } \\
\text { (skor 6) }\end{array}$ & $\begin{array}{l}\text { Box F } \\
\text { (skor } 8)\end{array}$ \\
\hline $\begin{array}{l}\text { (C) Efek samping yang menyebabkan } \\
\text { kematian dari obat yang } \\
\text { underdose atau overdose }\end{array}$ & $\begin{array}{l}\text { Box G } \\
\text { (skor 6) }\end{array}$ & $\begin{array}{c}\text { Box H } \\
\text { (skor 8) }\end{array}$ & $\begin{array}{c}\text { Box I } \\
\text { (skor 10) }\end{array}$ \\
\hline 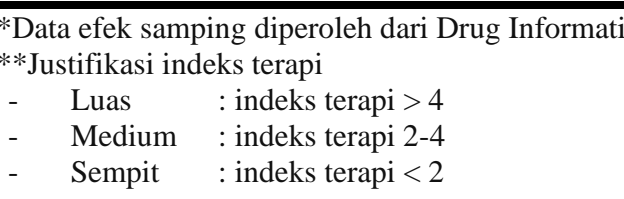 & & & \\
\hline
\end{tabular}

Resep dengan total resiko tertinggi akan dikaji aspek inkompatibilitas dan instabilitasnya menggunakan berbagai literatur secara sistematis. Literatur yang digunakan adalah kompendia (farmakope), database daring (pubchem, drugbank), dokumen atau artikel dari situs resmi (BPOM, KeMenKes, FDA, WHO, dll), buku referensi, dan berbagai artikel ilmiah. Pencarian artikel ilmiah dilakukan secara sistematis menggunakan bantuan mesin pencari google scholar dan PubMed dengan pengaturan batas minimal artikel adalah terbitan tahun 2008. Kata kunci yang digunakan untuk pencarian adalah nama masing-masing obat, stabilitas/stability of (nama obat), inkompatibilitas/incompatibility of (nama obat atau gugus fungsi obat), interaksi obat/pharmaceutical drug interaction of (nama obat), degradasi/degradation of (nama obat atau gugus fungsi obat).

\section{Hasil dan Pembahasan}

\subsection{Analisis Risiko}

Resep racikan yang mengandung amitriptilin (AMT), trifluoperazin dihidroklorida (TFP), dan alprazolam (ALP) memiliki total resiko 16 dari maksimal skor 20. Peracikan AMT, TFP, dan ALP termasuk dalam kategori resiko sangat tinggi, berdasarkan kategori yang ditetapkan pada handbook of extemporaneus preparation (Jackson and Lowey, 2010). Pada analisis risiko teknis, ditetapkan nilai 8 karena kerumitan perhitungan termasuk kategori sedang karena pada saat proses perhitungan diperlukan ketelitian yang lebih karena ada perbedaan kekuatan pada bentuk sediaan yang tersedia dan yang diminta pada resep, sedangkan untuk kerumitan proses peracikan termasuk kategori tinggi karena peracikan dilakukan menggunakan blender. Peracikan dengan blender berisiko menyebabkan kerusakan pada obat (reaksi oksidasi atau 
degradasi akibat suhu tinggi) dan campuran tidak homogen. Selain itu penggunaan blender juga dapat menyebabkan kontaminasi silang apabila blender tidak dibersihkan dengan benar. Apabila terdapat obat poten tertinggal, maka dapat membahayakan pasien (Thong et.al., 2018).

Analisis risiko klinis memiliki nilai 8 karena diantara ketiga obat tersebut, AMT memiliki indeks terapi yang sempit, dengan risiko apabila terjadi ketidaksesuaian dosis dapat menyebabkan neuroleptik, hipotensi, dan aritmia (Thanacoody and Thomas, 2005). Obat-obat dengan indeks terapi sempit harus diperhatikan karena jika terjadi ketidaksesuaian dosis sedikit saja dapat menyebabkan toksisitas bagi pasien. Hal ini perlu menjadi perhatian bagi tenaga kefarmasian yang melakukan peracikan sediaan ini untuk menjamin keseragaman dosis sediaannya.

Berdasarkan kajian risiko diatas, maka secara garis besar risiko terbesar yang mungkin dihadapi dalam peracikan ini adalah ketidakseragaman dosis pada sediaan racikan yang dapat berakibat buruk/berbahaya bagi pasien. Beberapa upaya saat proses peracikan dapat dilakukan untuk mencegah terjadinya kesalahan dalam peracikan, yaitu memisahkan blender untuk obat poten dan non poten, menambahkan pewarna (contoh: carmin) sebagai indikator homogenitas, dan menimbang satu persatu serbuk sesuai jumlah yang diminta sebelum dimasukkan ke cangkang kapsul. Kesalahan perhitungan dicegah dengan adanya verifikasi hasil perhitungan oleh orang lain.

\subsection{Potensi instabilitas dan inkompatibilitas}

Salah satu tanggung jawab apoteker dalam melakukan pekerjaan kefarmasian di instalasi farmasi rumah sakit adalah melakukan skrining resep, untuk memastikan aspek administrasi, farmasetis, dan klinis dari resep tersebut sudah sesuai (Kementrian Kesehatan Republik Indonesia, 2016). Pada aspek farmasetis, apoteker diharapkan mampu untuk mengkaji apakah dalam resep terdapat potensi instabilitas dan inkompatibilitas. Berdasarkan hasil wawancara dengan apoteker di rumah sakit tempat bekerja, skrining aspek farmasetis jarang dilakukan secara mendalam karena keterbatasan waktu dan minimnya sumber daya manusia, sehingga hanya dilakukan berdasarkan pengetahuan dan pengalaman yang dimiliki oleh apoteker. Potensi instabilitas dan inkompatibilitas ditinjau berdasarkan studi literatur dari berbagai penelitian.

Potensi instabilitas dan inkompatibilitas dilakukan dengan melihat sifat fisika dan kimia zat aktif masing-masing komponen, serta berdasarkan studi stabilitas atau studi kompatibilitas obat berdasarkan publikasi ilmiah. Studi stabilitas atau studi kompatibilitas dalam publikasi ilmiah dilakukan dalam "stress condition" baik dari aspek $\mathrm{pH}$, suhu, oksidattor, maupun kelembaban. Meskipun proses peracikan di instalasi farmasi tidak dilakukan dalam "stress 
condition", data stabilitas dan kompatibilitas pada studi-studi tersebut tetap digunakan sebagai pertimbangan. Hal ini dilakukan sebagai bentuk antisipasi terhadap potensi instabilitas dan inkompatibilitas dalam kondisi "worst case” akibat berbagai variabel-variabel pengacau yang tidak dapat dikendalikan. Dalam handbook of extemporaneous preparation dinyatakan bahwa dalam melakukan analisis risiko, sekecil apapun risiko yang mungkin terjadi pada sediaan racikan dan pasien, maka hal tersebut tetap menjadi risiko yang harus dipertimbangkan (Jackson and Lowey, 2010). Apabila dalam literatur/studi menunjukkan adanya potensi instabilitas atau inkompatibilitas, maka faktor pemicu tersebut tetap dipertimbangkan dapat berisiko menyebabkan instabilitas dan inkompatibilitas..

\subsubsection{Sifat fisika kimia AMT, TFP, ALP}

Pengetahuan dan pemahaman mengenai sifat fisika dan kimia molekul obat diperlukan untuk dapat melihat potensi instabilitas dan inkompatibilitas. Sifat fisika dan kimia AMT, TFP, dan ALP dapat diamati pada Tabel 3.

Tabel 3. Sifat fisika dan kimia amitriptilin, trifluoperazin dihidroklorida, dan alprazolam (Departemen Kesehatan Republik Indonesia, 2014).

\begin{tabular}{|c|c|c|c|}
\hline Parameter & $\begin{array}{l}\text { Amitriptilin } \\
\text { Hidroklorida }\end{array}$ & $\begin{array}{l}\text { Trifluoperazine } \\
\text { dihidroklorida }\end{array}$ & Alprazolam \\
\hline $\begin{array}{l}\text { Rumus } \\
\text { molekul }\end{array}$ & $\mathrm{C}_{20} \mathrm{H}_{23} \mathrm{~N} . \mathrm{HCl}$ & $\mathrm{C}_{6} \mathrm{H}_{24} \mathrm{~F}_{3} \mathrm{~N}_{3} \mathrm{~S} .2 \mathrm{HCl}$ & $\mathrm{C}_{17} \mathrm{H}_{13} \mathrm{ClN}_{4}$ \\
\hline Bobot molekul & 313,86 & 480,42 & 308,77 \\
\hline Organoleptis & $\begin{array}{l}\text { serbuk hablur atau } \\
\text { hablur kecil, putih atau } \\
\text { hampir putih, tidak } \\
\text { berbau atau hampir } \\
\text { tidak berbau }\end{array}$ & $\begin{array}{l}\text { serbuk hablur, putih } \\
\text { sampai kuning pucat, } \\
\text { praktis tidak berbau, } \\
\text { rasa pahit }\end{array}$ & $\begin{array}{l}\text { serbuk hablur, putih } \\
\text { sampai hampir putih }\end{array}$ \\
\hline Kelarutan & $\begin{array}{l}\text { mudah larut dalam air, } \\
\text { etanol, kloroform, dan } \\
\text { metanol, serta tidak } \\
\text { larut dalam eter }\end{array}$ & $\begin{array}{l}\text { mudah larut dalam air, } \\
\text { larut dalam etanol, agak } \\
\text { sukar larut dalam } \\
\text { kloroform, tidak larut } \\
\text { dalam eter dan dalam } \\
\text { benzena. }\end{array}$ & $\begin{array}{l}\text { tidak larut dalam air, } \\
\text { sukar larut dalam } \\
\text { asetat, agak sukar larut } \\
\text { dalam aseton, larut } \\
\text { dalam etanol, dan } \\
\text { mudah larut dalam } \\
\text { kloroform }\end{array}$ \\
\hline Higroskopisitas & $\begin{array}{l}\text { Bentuk garam, } \\
\text { cenderung higroskopis }\end{array}$ & $\begin{array}{l}\text { Bentuk garam, } \\
\text { cenderung higroskopis }\end{array}$ & Tidak higroskopis \\
\hline Titik lebur & antara $195^{\circ} \mathrm{C}$ dan $199^{\circ} \mathrm{C}$ & $\pm 242^{\circ} \mathrm{C}$ & $\pm 225^{\circ} \mathrm{C}$ \\
\hline $\mathrm{pH}$ & $5-6$ & $1,7-2,6$ & $2,9-11$ \\
\hline
\end{tabular}

Setiap senyawa memiliki gugus fungsi yang masing-masing berperan dalam reaksi tertentu. Rangkuman data stabilitas AMT, TFP, dan ALP berdasarkan reaksi yang mungkin terjadi pada gugus fungsi masing-masing dapat diamati pada Tabel 4. 
Tabel 4. Gugus fungsi dan potensi reaksi pada amitriptilin (AMT), trifluoperazin dihidroklorida (TFP), dan alprazolam (ALP).

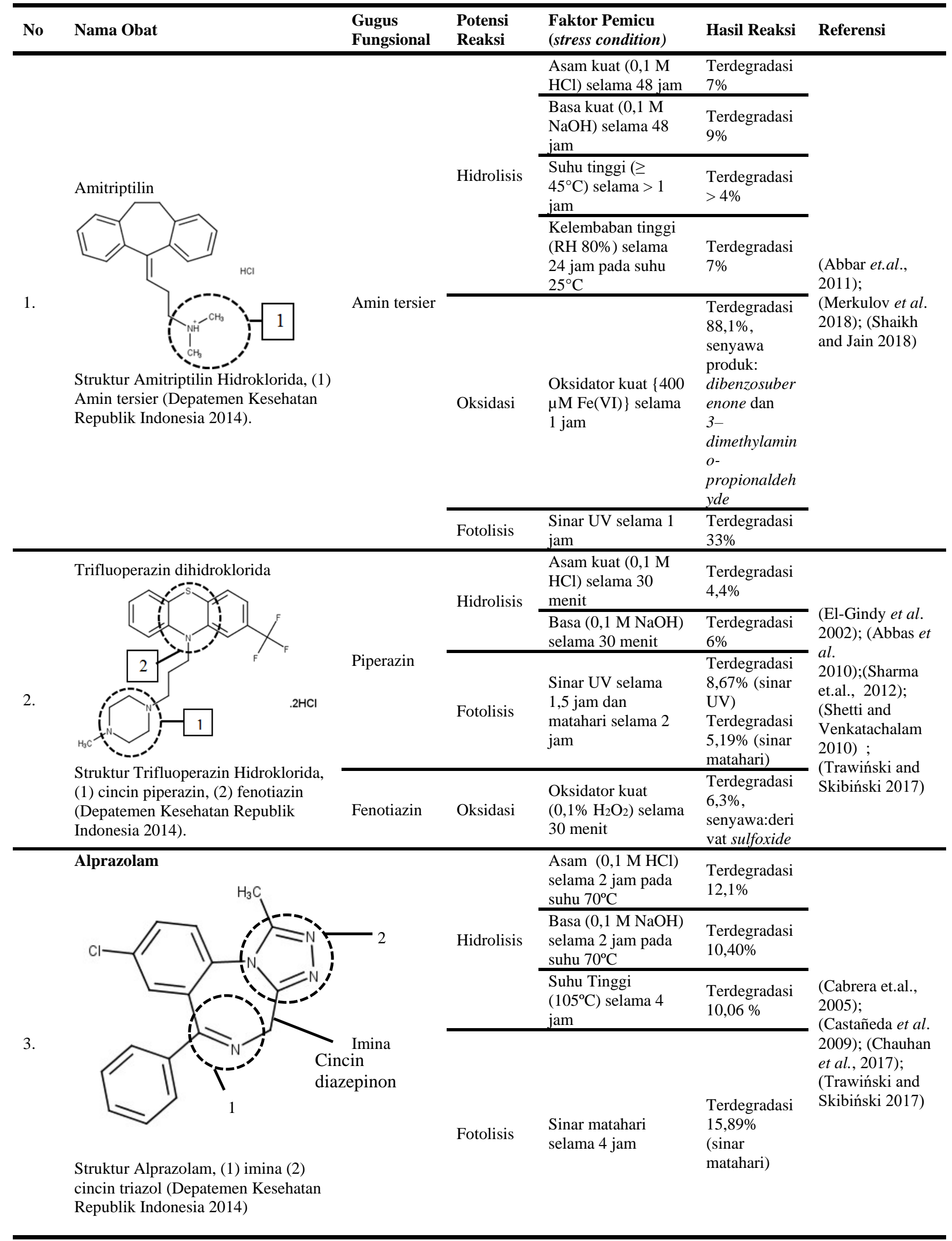




\subsubsection{Potensi instabilitas dan inkompatibilitas}

Sifat fisika dan kimia obat yang telah dirangkum dalam Tabel 3 dan Tabel 4 dapat digunakan untuk memperkirakan instabilitas dan inkompatibilitas yang mungkin terjadi. Resep racikan kombinasi AMT, TFP dan ALP memiliki beberapa permasalahan. Pertama, AMT dan TFP merupakan obat dalam bentuk garam. Obat dalam bentuk garam bersifat higroskopis (memiliki kemampuan menyerap dan menahan lembab pada berbagai suhu dan kelembaban) (Gupta et al., 2018). Sifat tersebut mendasari pabrik farmasi membuat sediaan AMT dan TFP dalam bentuk tablet salut.

AMT, TFP, dan ALP merupakan tablet salut film (Anonim 2017). Salut film berfungsi untuk menutupi rasa dan bau obat yang tidak enak, serta menjaga stabilitas obat dari pengaruh kelembaban dan cahaya (Gaur et al., 2014; Gracia-Vásquez et al., 2017). Kegiatan memotong atau menghancurkan tablet salut film dapat menurunkan stabilitas obat (Royal Pharmaceutical Society, 2011), dalam hal ini menyebabkan ketiga obat tersebut terpapar oleh udara dan lembab.

Kelembaban dalam serbuk tidak boleh dianggap remeh karena dapat memicu pertumbuhan mikroba, mengurangi estetika, dan merusak bahan aktif. Diketahui bahwa AMT dan ALP berpotensi mengalami hidrolisis karena pengaruh lembab (Castañeda et al., 2009; Gonsalves et al., 2010; Shaikh and Jain., 2018). Potensi hidrolisis semakin meningkat karena berdasarkan data BMKG Jawa Tengah (2019), RH rata-rata di Kota Semarang berkisar antara 60-95\%, yang berati kelembaban udara tinggi. Hal ini berpotensi merusak AMT dan ALP dalam sediaan kapsul yang terbuat dari gelatin karena kapsul juga dapat mengalami instabilitas fisik yaitu menjadi lembek apabila disimpan pada kelembaban tinggi (Allen., 2015).

Permasalahan kedua yaitu AMT, TFP, dan ALP diketahui tidak stabil terhadap paparan cahaya matahari atau sinar UV (Chauhan et al., 2017; Shetti and Venkatachalam, 2010; Trawiński and Skibiński, 2017). Oleh sebab itu, pada saat proses pembuatan dan penyimpanan harus dijauhkan dari jangkauan sinar matahari, tidak boleh dikemas di plastik klip biasa karena dapat merusak obat.

Ada beberapa alternatif yang dapat dilakukan untuk mengatasi potensi instabilitas dan inkompatibilitas yang mungkin terjadi, yaitu menggunakan cangkang kapsul dari hydroxypropyl methylcellulose (HPMC). Kapsul HPMC memiliki stabilitas yang lebih baik dibandingkan kapsul gelatin dan kompatibel dengan material higroskopik (Al-Tabakha, 2010). Sediaan kapsul yang dihasilkan juga disimpan dalam wadah tertutup rapat, terhindar dari cahaya matahari, pada suhu kamar. Penambahan silika gel juga dapat dilakukan untuk menyerap kelembaban udara sehingga obat tetap kering dan stabil ( Chen, 2017). 
Berdasarkan hasil studi ini, tenaga kefarmasian di rumah sakit harus melakukan pengkajian dan analisis terhadap resep-resep racikan di rumah sakit yang memiliki risiko tertinggi atau frekuensi kemunculan tertinggi, sebagai salah satu bentuk penjaminan mutu sediaan racikan. Tenaga kefarmasian harus mampu memahami setiap aspek fisika dan kimia dari suatu obat, sehingga dapat melakukan skrining resep dengan baik, terutama dalam memperkirakan terjadinya instabilitas dan inkompatibilitas dari suatu resep sediaan racikan. Tenaga farmasi juga harus memiliki bekal pengetahuan yang baik untuk dapat memberikan solusi terbaik jika terdapat permasalahan dalam sediaan racikan.

\section{Kesimpulan}

Peracikan kapsul dengan kandungan AMT, TFP, dan ALP termasuk dalam kategori risiko tinggi baik secara teknis maupun klinis. Sediaan racikan yang dihasilkan juga berpotensi mengalami instabilitas dan inkompatibilitas. Berbagai upaya teknis dapat dilakukan oleh tenaga kefarmasian untuk meningkatkan kualitas obat dan menjamin keamanannya yaitu menggunakan cangkang kapsul HPMC, menyimpan sediaan dalam wadah tertutup kedap, terhindar dari cahaya langsung pada suhu ruang dan menambahkan silika gel. Meskipun demikian, potensi instabilitas dan inkompatibilitas yang ditemukan dalam studi ini masih berdasar pada kajian pustaka, sehingga perlu dilakukan penelitian eksperimental untuk mengetahui profil stabilitas dan kompatibilitas sediaan racikan tersebut.

\section{Ucapan Terimakasih}

Penelitian ini dilakukan dengan bantuan hibah penelitian internal dosen muda LPPM USD dengan nomor kontrak 026/Penel./LPPM-USD/IV/2018.

\section{Daftar Pustaka}

Abbar, J.C., Shekappa, D.L., and Sharanappa, T.N. (2011). "Ruthenium (III) Catalyzed Oxidative Degradation of Amitriptyline-A Tricyclic Antidepressant Drug by Permanganate in Aqueous Acidic Medium." Journal of solution chemistry, 40(3), pp: $502-520$.

Abbas, S.S., Zaazaa, H.E., Abdelkawy, M. and Abdelrahman, M.M. (2010). "Spectrophotometric Determination of Isopropamide Iodide and Trifluoperazine Hydrochloride in Presence of Trifluoperazine Oxidative Degradate." Drug testing and analysis, 2(4), pp. 168-181.

Allen, L.V. (2015). "Secundum Artem: Compounding Capsule." perrigo. http://www.perrigo.com/business/pdfs/Sec\%Artem\%204.4.pdf. diakses tanggal 20 Agustus 2019

Al-Tabakha, M.M. (2010). "HPMC Capsules: Current Status and Future Prospects." Journal of Pharmacy \& Pharmaceutical Sciences, 13(3), pp.428-442. 
Amalia, D.T. and Sukohar, A. (2014). "Rational Drug Prescription Writing." Juke Unila, 4(01), pp. 22-30.

Anonim. 2017. 18 MIMS. Jakarta: BIP.

Boodoo, J.M. (2010). "Compounding Problems and Compounding Confusion: Federal Regulation of Compounded Drug Products and the FDAMA Circuit Split." American Journal of Law \& Medicine, 36(1), pp. 221-48.

Cabrera, C.G., R. de Waisbaum, G., and Nudelman, N.S. (2005). "Kinetic and Mechanistic Studies on the Hydrolysis and Photodegradation of Diazepam and Alprazolam." Journal of physical organic chemistry, 18(2), pp. 156-161.

Castañeda, B., Ortiz-Cala, W., Gallardo-Cabrera, C., and Nudelman, N.S. (2009). "Stability Studies of Alprazolam Tablets: Effects of Chemical Interactions with Some Excipients in Pharmaceutical Solid Preparations." Journal of Physical Organic Chemistry, 22(9), pp. 807-814.

Chauhan, P.P., Patel, D.Y. and Shah, S.K. (2017). "Optimization of Stability Indicating RPHPLC Method for The Estimation of an Antidepressant Agents Alprazolam and Imipramine in Pure \& Pharmaceutical Dosage Form." Eurasian Journal of Analytical Chemistry, 11(2), pp. 101-13.

Chen, Y. (2017). "Packaging Selection for Solid Oral Dosage Forms.” In Developing Solid Oral Dosage Forms, Elsevier, pp. 637-651.

Chollet, J.L., and Jozwiakowski, M.J. (2012). "Quality Investigation of Hydroxyprogesterone Caproate Active Pharmaceutical Ingredient and Injection." Drug development and industrial pharmacy, 38(5), pp. 540-549.

Depatemen Kesehatan Republik Indonesia. 2014. Farmakope Indonesia. Edisi V. Jakarta: Departemen Kesehatan Republik Indonesia.

El-Gindy, A., El-Zeany, B., Awad, T. and Shabana, M.M. (2002). "Derivative Spectrophotometric, Thin Layer Chromatographic-Densitometric and HighPerformance Liquid Chromatographic Determination of Trifluoperazine Hydrochloride in Presence of Its Hydrogen Peroxide Induced-Degradation Product." Journal of pharmaceutical and biomedical analysis, 27(1-2), pp. 9-18.

Gaur, P.K., Mishra,S., Gautam, R., Singh, A.P. and Yasir, M. (2014). "Film Coating Technology: Past, Present and Future." Journal of Pharmaceutical Sciences and Pharmacology, 1(1), pp. 57-67.

Gonsalves, A.R, Pineiro, M., Martins, J.M., Barata, P.A. and Menezes, José C. (2010). "Identification of Alprazolam and Its Degradation Products Using LC-MS-MS." Arkivoc, 128: 141.

Gracia-Vásquez, S.L., González-Barranco, P., Camacho-Mora, I.A., González-Santiago O., Vázquez-Rodríguez. S.A. (2017). "Medications That Should Not Be Crushed." Medicina Universitaria, 19(75), 50-63.

Gudeman, J., Jozwiakowski, M., Chollet, J., and Randell, M. (2013). "Potential Risks of Pharmacy Compounding." Drugs in R\&D, 13(1), pp. 1-8. 
Gupta, D., Bathia, D., Dave, V., Sutariya, V., and Gupta, S.V. (2018). "Salts of Therapeutic Agents: Chemical, Physicochemical, and Biological Considerations.” Molecules, 23(7), pp. 1719.

Mark, J. and Lowey, A. (2010). Handbook of Extemporaneous Preparation. Pharmaceutical Press. http://www.pharmpress.com/product/9780853699019/pdf/HEP_monograph.pdf (October 11, 2016).

Kementrian Kesehatan Republik Indonesia. 2016. "Peraturan Menteri Kesehatan No 72 Tahun 2016 Tentang Standar Pelayanan Kefarmasian Di Rumah Sakit.”

Merkulov, S., Despotović V.N., Banić N.D., Armaković S.J., Finčur N.L., Lazarević M.J., Četojević-Simin D.D., Orčić D.Z., Radoičić M.B., Šaponjić Z.V., Čomor M.I., Abramović B.F. (2018). "Photocatalytic Decomposition of Selected Biologically Active Compounds in Environmental Waters Using TiO2/Polyaniline Nanocomposites: Kinetics, Toxicity and Intermediates Assessment." Environmental pollution, 239, pp. $457-465$.

Nahata, M.C., and Allen, L.V. (2008). "Extemporaneous Drug Formulations." Clinical Therapeutics, 30(11), pp. 2112-2119.

Royal Pharmaceutical Society. (2011). "Pharmaceutical Issues When Crushing, Opening or Splitting Oral Dosage Forms." https://www.rpharms.com/Portals/0/RPS\%20document\%20library/Open\%20access/Su pport/toolkit/pharmaceuticalissuesdosageforms-\%282\%29.pdf. diakses tanggal 20 Agustus 2019

Shaikh, S. and Jain, V. (2018). "Development and Validation of Novel RPHPLC Method for Simultaneous Estimation of Gabapentine and Amitriptyline Hydrochloride in Bulk and Pharmacetical Dosage Forms." International Journal of Applied Pharmaceutics, 10(2), pp. 97-104.

Sharma, K., Agrawal, S.S. and Gupta, M. (2012). "Development and Validation of UV Spectrophotometric Method for the Estimation of Curcumin in Bulk Drug and Pharmaceutical Dosage Forms." International Journal of Drug Development \& Research, 4(2), pp. 375-80.

Shetti, P. and Venkatachalam, A. (2010). "Stability Indicating HPLC Method for Simultaneous Quantification of Trihexyphenidyl Hydrochloride, Trifluoperazine Hydrochloride and Chlorpromazine Hydrochloride from Tablet Formulation.” Journal of Chemistry, 7(S1), pp. S299-S313.

Thanacoody, H.K.R and Thomas, S.H.L. (2005). "Tricyclic Antidepressant Poisoning." Toxicological reviews, 24(3), pp. 205-214.

Thong, M.Y., Manrique, Y.J. and Steadman, K.J. (2018). "Drug Loss While Crushing Tablets: Comparison of 24 Tablet Crushing Devices.” PLOS ONE, 13(3), pp. 0193683.

Trawiński, J. and Skibiński, R. (2017). "Studies on Photodegradation Process of Psychotropic Drugs: A Review." Environmental Science and Pollution Research, 24(2), pp. 11521199. 
Wiedyaningsih, C. and Suryawati, D.R. S. (2013). "Faktor Pendorong Peresepan Racikan Untuk Pasien Anak Rawat Jalan.” PhD Thesis. Universitas Gadjah Mada.

\section{(c) (1) ()}

BY SA O 2019 by the authors. Submitted for possible open access publication under the terms and conditions of the Creative Commons Attribution-ShareAlike 4.0 International (CC BY-SA 4.0) license (https://creativecommons.org/licenses/by-sa/4.0/). 